\title{
Accumulation of heavy minerals in the eastern coast of the Gulf of Riga, south-western Estonia
}

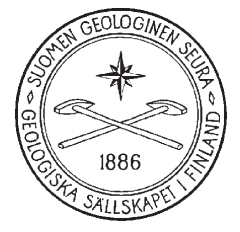

\author{
Johanna-Iisebel Järvelill ${ }^{1 *}$, Anne KleEsment ${ }^{2}$ \\ AND ANTO RAUKAS 3 \\ 1 Institute of Mathematics and Natural Sciences, Tallinn University, \\ 10120 Tallinn,Estonia, iisebel@hotmail.com \\ 2 Institute of Geology, Tallinn University of Technology, 19086 Tallinn, Estonia \\ ${ }^{3}$ Institute of Ecology, Tallinn University, 10120 Tallinn, Estonia
}

\begin{abstract}
The Baltic Sea is characterised by tectonic conditions that cause its northern parts to lift and southern parts to sink. Our study area (eastern coast of the Gulf of Riga) has been rather stable for a long time. During transgressive phases in the course of the sea's invasion to the coast intensive mechanical and mineralogical differentiation of the sediments took place, causing the separation of heavy minerals. The largest concentrations of heavy minerals were found in transgressive sediments of the Litorina Sea. Their concentration was especially high in the Lemmeoja site (in some layers up to $83.7 \%$ of the sediment). The goal of our research was to study the heavy mineral content and composition in different age sediments of the area and to find regularities in the accumulation processes through time. To achieve our aim we collected samples from 16 sites between Pärnu and Ikla in south-western Estonia. The heavy mineral content in the whole investigated area is high, amounting on average to about $5 \%$. The deposits of transgressive phases of the Baltic Sea are more reworked than those of the regressive phases and contain more heavy minerals. Our investigation of initial rocks allows to conclude that garnets and zircon originated mainly from the Devonian sandstones of the Aruküla and Narva regional stages, amphiboles and pyroxenes mainly from Quaternary deposits.
\end{abstract}

Keywords (GeoRef Thesaurus, AGI): transgression, sea-level changes, heavy minerals, Baltic Sea, Gulf of Riga

* Corresponding author e-mail: iisebel@hotmail.com

Editorial handling: Pertti Sarala (pertti.sarala@gtk.fi) 


\section{Introduction}

Elevated radioactive elements' levels of $\mathrm{U}, \mathrm{K}$ and Th, caused by the content of heavy minerals in the ground, have been detected in various parts of Estonia (Petersell et al., 2015). However, heavy minerals, mainly zircon and monazite, may also be of practical importance. The intensive accumulation of heavy minerals took place in the course of the water invasion during the transgressive phases of the Baltic Sea due to selective mechanical and mineralogical differentiation (Raukas, 1991).

Estonia's about $3780 \mathrm{~km}$ long coastline is indented by numerous bays, inlets, and straits. Straight sandy beaches with a complicated crossand longshore migration of sedimentary material and a low tectonic uplift are characteristic only of north-eastern and south-western Estonia, including our study area on the eastern coast of the Gulf of Riga. This area is promising for heavy mineral studies. However, heavy minerals in the coastal deposits of this area have never before been systematically investigated. Only the neighbourhood of the small stream Lemmeoja in south-western Estonia was studied earlier by Luntz \& Maiore (1960) and by the third author (Kessel \& Raukas, 1967). This is also the area where the highest concentrations of heavy minerals have been found so far (Raukas, 1964).

\section{Material and Methods}

\subsection{Study area}

We investigated the coastal deposits in the eastern coast of the Gulf of Riga between Pärnu and the Estonian/Latvian border at Ikla/Ainaži (Fig. 1). In this area straight sandy beaches are characteristic.

The Gulf of Riga was shaped by Pleistocene glaciers. The shallow (maximum depth $67 \mathrm{~m}$ ) gulf is enclosed by the West-Estonian Archipelago and it cuts into the Estonian and Latvian mainland. The gulf receives $30.7 \mathrm{~km}^{3}$ of its water from rivers and $10.3 \mathrm{~km}^{3}$ from rainfall. Salinity is low (3.5-6.5\%). In the study area the $5 \mathrm{~m}$ isobath is $10-15 \mathrm{~km}$ from the shore.

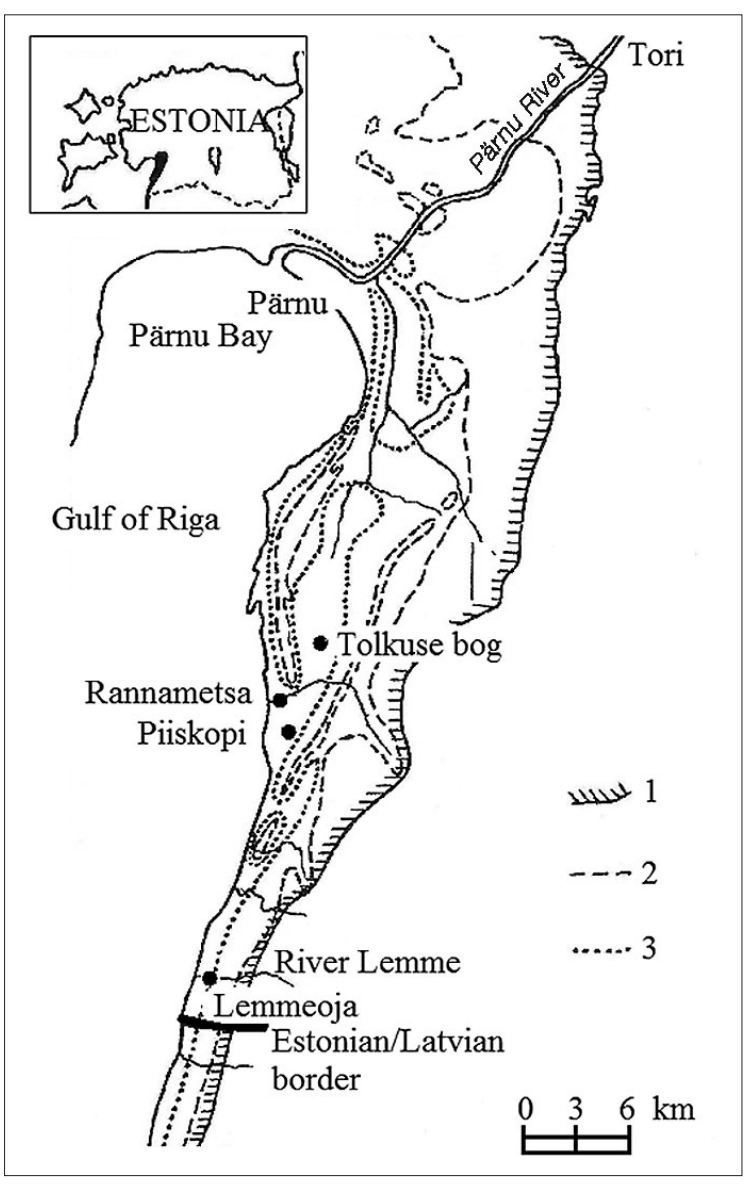

Fig. 1. Ancylus and Litorina shorelines in the study area. 1 - the highest shoreline of the Ancylus Lake; 2 - shoreline of the regressive Ancylus Lake; 3 - the highest shoreline of the Litorina Sea.

The central area of the gulf stretches across a symmetrical depression, which is elongated from the north-west to the south-east. The depth in this depression regularly lessens towards the Island of Ruhnu, which divides the central deep of the gulf into two sections. The island itself represents the highest point of an elongated bedrock elevation angling north-west to south-east and rising above the sea level. Like the central deep, this drumlinlike elevation with its steeper proximal and more gently-falling distal slopes was largely moulded by the Central-Latvian glacier lobe. Six sites were investigated in the neighbourhood of the small Lemmeoja River, which begins in Nigula Bog and enters the Gulf of Riga from the village of Kabli to the south. Eifelian sandstone of the Middle 
Devonian Aruküla Regional Stage, covered with a thin layer of reddish-brown till from the last glaciations, crops near the river mouth (Reintam et al., 2001).

\subsection{Geological setting and geological history of the area}

The bedrock in the study area consists of Devonian rocks (Fig. 2), which crop out only in some locations. Feldspatic quartz sandstone varieties prevail. Silty formations of the Narva and Aruküla stages are mainly sandstone with mica-rich feldspatic quartz. A higher content of quartz occurs only in deposits of the Pärnu Stage. In the 1960s the mineralogy of Devonian rocks was studied by Viiding $(1962 ; 1964)$. Since the 1970s the second author has published several studies on Devonian rocks (Kleesment, 1976; Kleesment \& Mark-Kurik, 1997; Kleesment, 2009). According to her studies, ilmenite prevails amongst the heavy allogenic minerals, and its proportion increases from the Pärnu Stage (35\%) to the Aruküla Stage (51\%). Within the Pärnu Stage, the prevailing transparent allogenic mineral is garnet. Within the Narva Stage apatite-garnet or apatite-tourmaline associations are typical. In the lower part of the Aruküla Stage, the mineral composition is similar to the Narva Stage, but in the upper part a garnet-zircon association occurs. Within the Burtnieki Stage, tourmaline, zircon, and staurolite are common. MiddleDevonian rocks contain episodically micas, epidote, titanite, hornblende, and pyroxenes. Of the authigenic minerals, iron hydroxides (mainly goethite), leucoxene, and carbonates can be found. In addition, biogenic apatite is frequent there while pyrite and barite are less common.

Devonian rocks are covered with Quaternary deposits up to 30-40 m thick (Raukas, 1978). Main deposit is the till of the last glaciation. Tills on the Devonian bedrock have reddish-brown colour and the content of coarse fractions is low. In comparison with the North-Estonian tills we see here a decrease of carbonate clasts, which are less resistant than magmatic and metamorphic rocks. In the sandy and silty fractions among the heavy subfraction after amphiboles and pyroxenes a significant role is enacted by minerals typical of the underlying Devonian rocks (zircon, tourmaline, garnets, and others). As a rule, the content of carbonate minerals in the sandy fractions does not exceed $10 \%$. Glaciofluvial and glaciolacustrine deposits have limited distribution and their role in recycling and deposition of heavy minerals is small. Till is covered mainly with marine and aeolian deposits of Ancylus Lake, Litorina Sea, and Limnea Sea. In Rannametsa dunes the Holocene deposits are up to 30 thick. (Raukas, 1961)

Bottom sediments in the northern part of the Gulf of Riga (in Pärnu Bay) are variable in composition and distribution. Fine material flows into the bay via rivers and it is also produced by bottom erosion (Kiipli \& Lutt, 1993).

In the coastal sediments the content of micas, biogenic apatite, and iron hydroxides decreases with decreasing grain size, but the content of epidote,

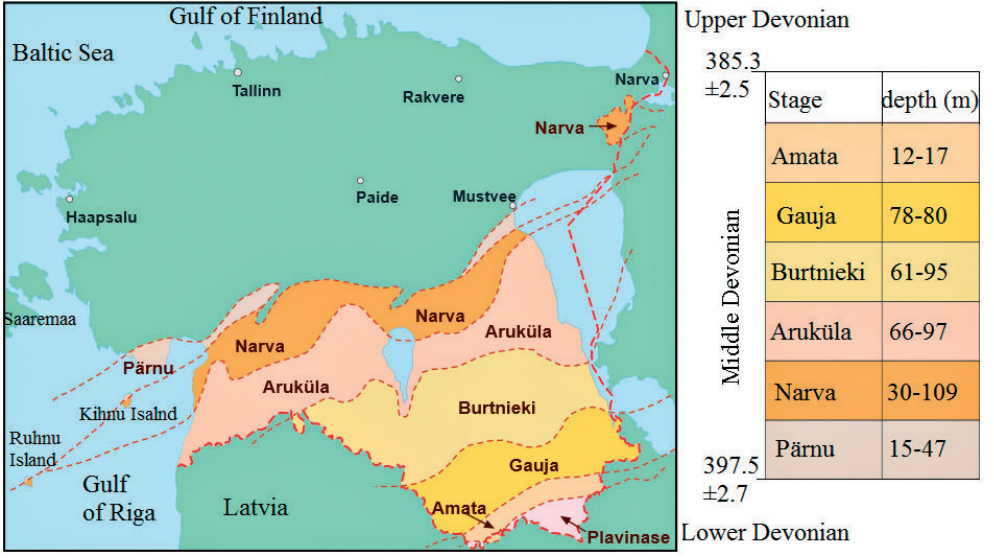

Fig. 2. Middle-Devonian regional stages in the study area (modified after Bedrock geological map of the Estonia made by the Geological Survey of Estonia). 
carbonates, pyrite, zircon, titanite, and rutile increases. Amphiboles, pyroxenes, and sillimanite are the most frequent minerals found in fine sand and coarse silt; garnets and apatite prevail in silt and tourmaline in the coarse silt fraction. The bottom sediments of Pärnu Bay have a high content of garnets (Table 1). The content of hydrous ferric oxides is also high while the content of pyrite is low (Lutt \& Popova, 1993).

The Late-Glacial drop of the Baltic Ice Lake lowered its water to the ocean level (the Yoldia Sea);

Table 1. Mineral content in the coarse silt (50-100 $\mu \mathrm{m})$ fraction of Pärnu Bay bottom deposits (I) after Lutt \& Popova (1993) and coastal minerals between Pärnu and Ikla in 125-250 $\mu \mathrm{m}$ (II) and 63-125 $\mu \mathrm{m}$ (III) fractions, \%

\begin{tabular}{|c|c|c|c|}
\hline Minerals & $\mathbf{I}$ & II & III \\
\hline \multicolumn{4}{|c|}{ Light minerals (under $2.89 \mathrm{~g} / \mathrm{cm}^{3}$ ) } \\
\hline Quartz & 63.5 & 81.3 & 65.8 \\
\hline Feldspars & 25.6 & 14.5 & 28.6 \\
\hline Micas & 0.5 & 3.1 & 3.0 \\
\hline Carbonates & 10.4 & 1.0 & 2.5 \\
\hline Glauconite & + & 0.1 & 0.1 \\
\hline Other minerals & + & - & \\
\hline \multicolumn{4}{|c|}{ Heavy minerals (over $2.89 \mathrm{~g} / \mathrm{cm}^{3}$ ) } \\
\hline Garnets & 22.8 & 37.3 & 25.0 \\
\hline Amphiboles & 35.7 & 26.1 & 19.1 \\
\hline Pyroxenes & 7.3 & 7.6 & 9.3 \\
\hline Zircon/monazite & 3.2 & 0.6 & 7.3 \\
\hline Green mica & \multirow{2}{*}{2.5} & 8.8 & 3.5 \\
\hline Brown mica & & 0.7 & 3.7 \\
\hline Tourmaline & 0.8 & 1.7 & 0.9 \\
\hline Apatite & 1.3 & 0.3 & 0.3 \\
\hline Carbonates & 4.7 & 7.0 & 14.6 \\
\hline Opaque minerals & 10.8 & 6.4 & 13.1 \\
\hline Iron hydroxides & 0.7 & 0.5 & 1.1 \\
\hline Rutile & \multirow{2}{*}{1.6} & 0.3 & 0.4 \\
\hline Titanite & & 0.2 & 0.2 \\
\hline Chlorites & - & 0.4 & 0.2 \\
\hline Epidote & 6.5 & 2.0 & 1.3 \\
\hline Corundum & - & 0.1 & + \\
\hline Leucoxene & 0.5 & - & - \\
\hline Pyrite & 0.1 & - & - \\
\hline Disthen & 0.5 & - & - \\
\hline Sillimanite, andalusite & 0.1 & - & \\
\hline Biogenic apatite & 0.4 & - & - \\
\hline Xenotime & - & + & + \\
\hline Lazurite & - & + & + \\
\hline Other minerals & 0.6 & - & \\
\hline
\end{tabular}

it was followed by a rapid transgression of the Ancylus Lake about $9500{ }^{14} \mathrm{C}$ years BP (Haila \& Raukas, 1992) and its regression in the late Ancylus period. The following Litorina transgression about 7600 years ago (8 412-8 387, median 8399 cal. years) was rather small, and after that the area has been regressive. In our study area we could investigate Ancylus, Litorina, Limnea $(4500 \mathrm{cal}$. years BP up to present), and contemporary sediments of different origin, mainly aeolian and beach sediments.

Coastal and submarine erosion along with the suspended load carried along by small rivers and brooks are the main sources of sedimentary material. Besides, erosion and transportation by wind and drift ice have some influence. Isolation, the modest size, and the shallow depth of the Gulf of Riga are factors that limit the development of significant currents, and tidal changes in the water levels are very small.

The principal coastal agent is the wave action, induced by heavy storms. The wind velocity reached $40 \mathrm{~m} / \mathrm{s}$ in 1954 and $45 \mathrm{~m} / \mathrm{s}$ in 1969. Such heavy storms, especially in the autumn-winter period when the water level is relatively high, pile up great water masses (Soomere et al., 2011). Under high water conditions, the surge can reach $2-3 \mathrm{~m}$ and cause severe damage along the coast. Significant wave heights may reach $4 \mathrm{~m}$ in the Gulf of Riga, when a storm wind blows from the direction of the longest fetch. There were quasi-periodic wave energy cycles with high stages in 1980-1995 and also after 2007, showing an overall decrease in mean wave properties, an increase in high wave events in windward locations and their relations with wind regimes (Suursaar et al., 2012).

Rapid changes on the beaches are also related to the force of the ice movement, euphemistically known as 'ice-push'. Ridges of pressure ice, up to 10-15 m high, are generated by persistent unidirectional winds and are pushed forwards against the shore with enormous force, playing a significant role in shaping the beach and transporting huge erratic boulders. In Pärnu, under the compressing and ploughing influence of ice, deep furrows are often formed on the beach and 
the coastal slope. During milder, ice-free winters, the erosion of beaches is much more intensive (Orviku et al., 2011).

\subsection{Sampling and analyses}

In order to detect the highest levels of heavy minerals in areas between Pärnu and the Estonian/Latvian border, in 2013-2014 the first author collected and analysed samples from 16 excavations with depths up to $1.6 \mathrm{~m}$ (Fig. 3). Altogether 49 samples were analysed. Grain-size analyses were conducted with an Analysette 3 Vibratory Sieve Shaker PRO using a sieve set with seven fractions: $>2000 \mu \mathrm{m}(-1 \varphi)$, $>1000 \mu \mathrm{m}(0 \varphi),>500 \mu \mathrm{m}(1 \varphi),>250 \mu \mathrm{m}(2 \varphi)$, $>125 \mu \mathrm{m}(3 \varphi),>100 \mu \mathrm{m}$, and $<63 \mu \mathrm{m}(4 \varphi)$. The light and heavy (over $2.89 \mathrm{~g} / \mathrm{cm}^{3}$ ) mineral suites were separated. About 300 mineral grains for the light subfraction and 500 grains for the heavy subfraction were counted in each mineral suite. The immersion method was applied, making use of liquids with the refractive indexes of 1.54 and 1.64 (Larsen \& Berman, 1934; Stoiber \& Morse, 1994). The results were analysed with the XLSTAT statistics program.

\section{Results and discussion}

\subsection{Analytical results from the study area}

In south-western Estonia heavy minerals abound on the seaward slope of the coastal bar in the deposits that were left behind by the Litorina transgression. In the $1.5-3 \mathrm{~m}$ thick complex their mean content amounts to $40 \%$ of all counted minerals. Heavy minerals are found in quartz-feldspar sands where they form interlayers with a thickness of a few millimetres up to $20 \mathrm{~cm}$. In these interlayers, the heavy fraction frequently accounts for 80-90\%. Most of Quaternary cover is transported to Estonia by glaciers, but they are mixed with the local bedrock material. The coastal development was obviously controlled by the crustal uplift along the coast, which in the past was more intensive (Gudelis, 1961).

The sediment core analysis made by the second author showed that in the Devonian rocks quartz dominates, accounting on average for $86 \%$ of all counted minerals in the $0.1-0.06 \mathrm{~mm}$ fraction. Only in some samples the content of quartz was under $70 \%$. Feldspars averaged at 12-13\%, along with prevailing orthoclase with some plagioclase and microcline. Grains are half-rounded and many samples are pigmented with iron oxi-hydroxides. The heavy mineral subfraction ranges from $0.7 \%$ to $3.5 \%$, and in some places (e.g. the Tori site) up to $26.8 \%$.

The heavy minerals in Devonian rocks are traditionally divided into two groups (Kleesment, 1976): transparent detrital minerals (garnets, zircon, apatite, etc.) and other minerals (ilmenite, leucoxene, etc.). Amongst transparent allogenic minerals garnets prevail, averaging at $60.7 \%$ of all counted minerals. In some samples their content was over $90 \%$. In the composition of transparent allogenic minerals also zircon (averaging $12 \%$ ),

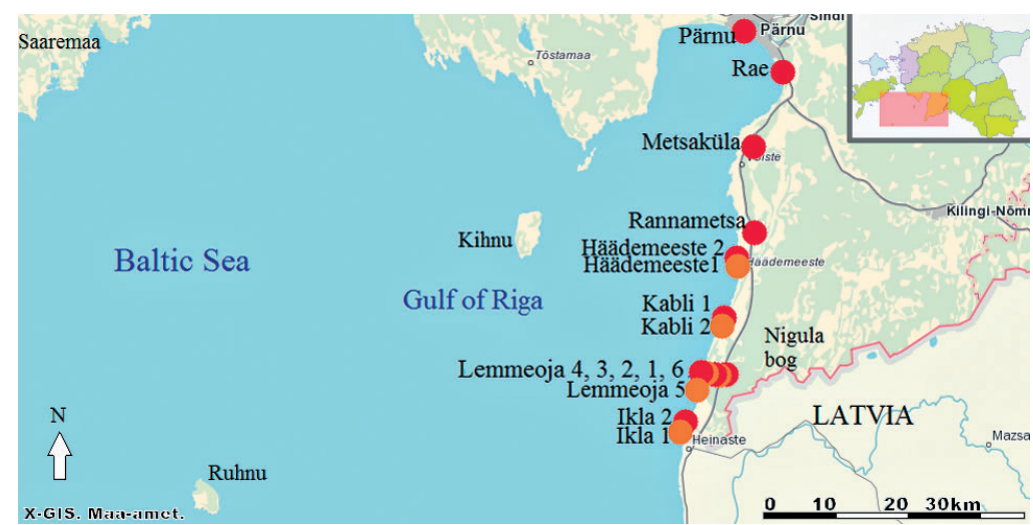

Fig. 3. Recently investigated sites between Pärnu and Ikla (south-western Estonia). 
tourmaline $(6.4 \%)$, and apatite (5.6 $\%)$ are important. As to other minerals, the content of opaque minerals, represented predominantly by ilmenite, is high (average $41.3 \%$ ). Micas form $0.5-35 \%$ and there are findings of pyrite.

The aeolian sediments grain-size composition of different ages in the study area is rather similar. More or less equal levels of sand content are characteristic. The sediments contain mostly fine-grained $(0.1-0.25 \mathrm{~mm})$ and medium-grained $(0.25-0.50 \mathrm{~mm})$ sand with fine sand clearly prevailing (up to $82 \%$ ) in some intervals. The content of coarse sand $(0.5-1.0 \mathrm{~mm})$ is less than $10 \%$ and that of silt fractions is rarely over $1 \%$. The bimineral deposits are well sorted (So 1.4-1.6, Md 0.17-0.31) and consist mainly of quartz (in fine sand at 71$94 \%$ ) and feldspars (6-22\%). Minerals of the heavy subfraction occur in relatively small amounts (0.74-4.40\%, mainly about $1 \%)$. The content of weathering-resistant minerals (quartz, garnets, zircon, etc.) is a little higher, while that of lamellate and tabular minerals (especially micas and chlorites) is lower than in the initial beach deposits. (Raukas, 1968)

\subsection{Analytical results of recently collected samples}

\subsubsection{Granulometry}

According to grain-size analyses, the $0.25-0.5 \mathrm{~mm}$ and $0.125-0.25 \mathrm{~mm}$ fractions prevail in the sediments. The median is from 0.785 to 2.876 . Sorting is from moderately well sorted to very poorly sorted (0.507-2.162); skewness from strongly negatively skew to strongly positively skew $(-0.380$ to

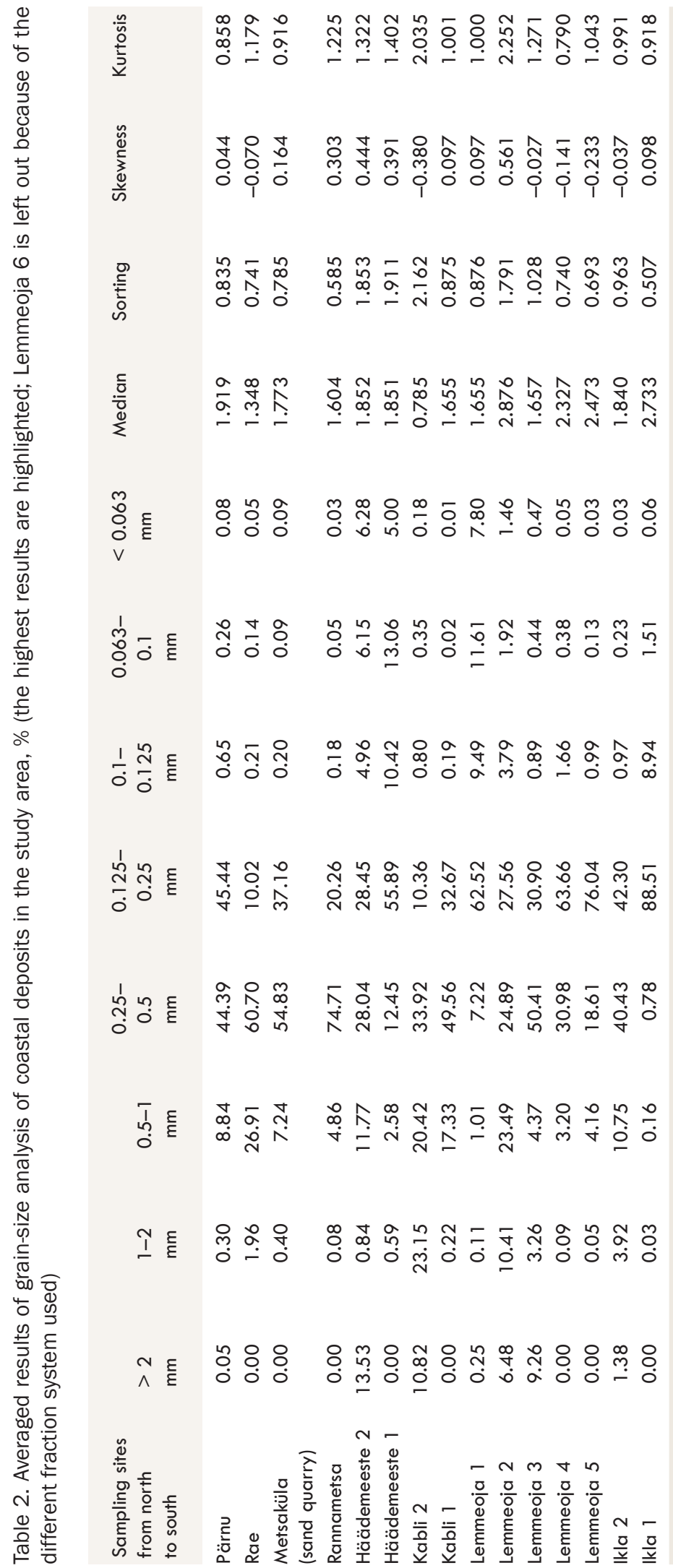


$+0.561)$; kurtosis is platycurtic, mesokurtic, leptokurtic, and very leptokurtic (0.790-2.252) (Table 2). The moderately well sorted samples originate in the Rannametsa, Lemmeoja 5, and Ikla 2 and 1 sites. The moderately sorted samples are from the Pärnu, Rae, Metsaküla quarry, Kabli 1, and Lemmeoja 1 and 4 sites. The poorly sorted samples came from the Häädemeeste 2 and 1 and Lemmeoja 2 and 3 sites. The only very poorly sorted sample is from the Kabli 2 site.

\subsubsection{Mineralogy}

The mineral composition of the samples was determined with a polarised microscope in the fractions of 125-250 $\mu \mathrm{m}, 100-150 \mu \mathrm{m}$, and 63$100 \mu \mathrm{m}$. Fraction 63-100 $\mu \mathrm{m}$ was analysed selectively. In most cases, the content of heavy minerals is less than $5 \%$ (weight percentage). At the same time in some sections (in the fraction of $125-250 \mu \mathrm{m})$ the content of heavy minerals was very high: at the Rae site it was up to $8.6 \%$, at Rannametsa up to $11.4 \%$, and at Lemmeoja up to $47.1 \%$. The $100-150 \mu \mathrm{m}$ fraction in the samples from Lemmeoja contained on average $39.2 \%$ heavy minerals.

Heavy minerals are concentrated in slices; for example, at Rae they occurred at a depth of $1.2 \mathrm{~m}$ (Fig. 4) and at Lemmeoja at a depth of 1.40-1.56 $\mathrm{m}$ (Fig. 5). In the fraction of $100-150 \mu \mathrm{m}$ an up to $83.7 \%$ content of heavy minerals was registered at a depth of $0.72-0.84 \mathrm{~m}$. The $125-250 \mu \mathrm{m}$ fraction at Lemmeoja 1 showed the highest concentration of zircon/monazite (3.9\%). A high content of these minerals $(2.5 \%)$ was found also in one sample from the Rae 1 site. The high content of zircon in the Lemmeoja area has caused high levels of radioactivity there (Raukas et al., 2014).

The green colour of epidotes indicates that their iron content is high. Amphiboles are mostly dark coloured, which is indicative of the high aluminium content. Garnets are mostly colourless. Zircons were mostly rounded (Fig. 6) and many of them are colourless with opaque inclusions suggesting to metamorphic provenance (Borgohain et al., 1999).

Comparison of the 125-250 and 63-125 $\mu \mathrm{m}$

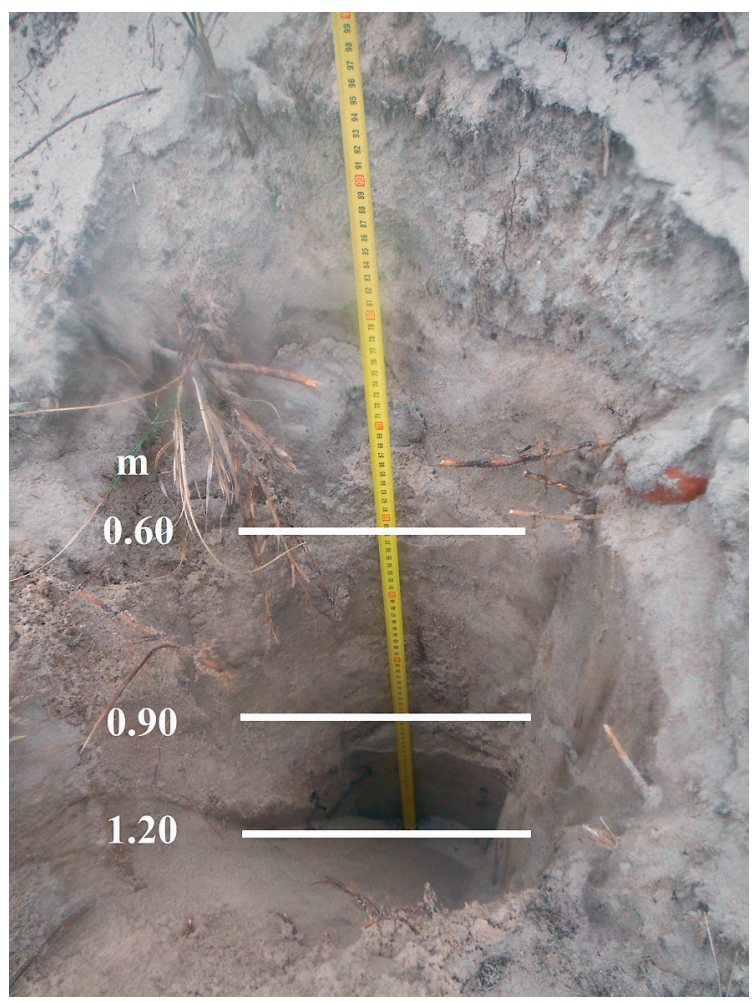

Fig. 4. Rae site, heavy minerals (up to $8.6 \%$ ) at a depth of $1.2 \mathrm{~m}$. Photo by J.-I. Järvelill.

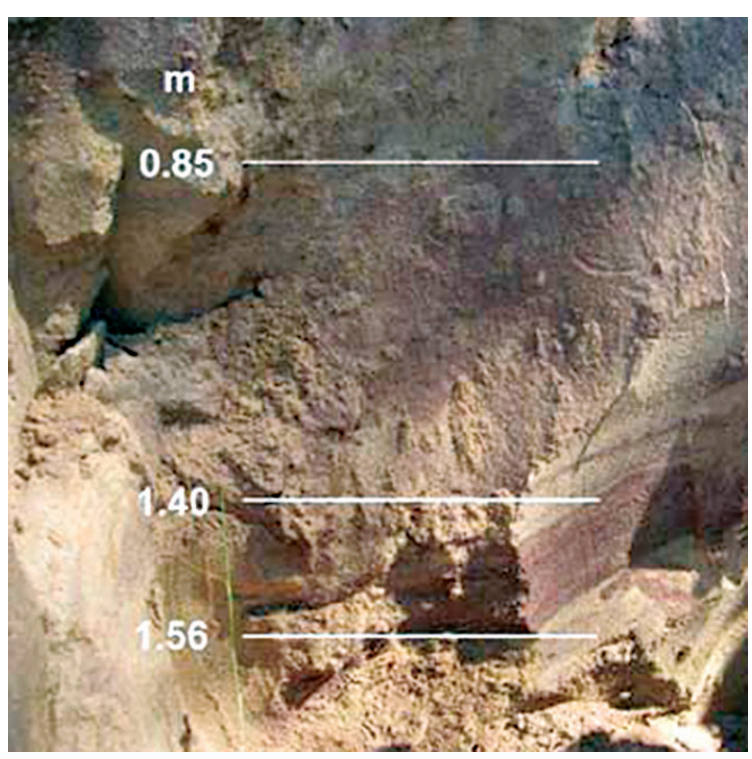

Fig. 5. Heavy minerals in the Lemmeoja 6 site with a high content (47.5\%) at a depth of 1.40-1.56 m and with an extremely high content (83.7 \%) at a depth of 0.72-0.84 m. Photo by K. Saarik. 

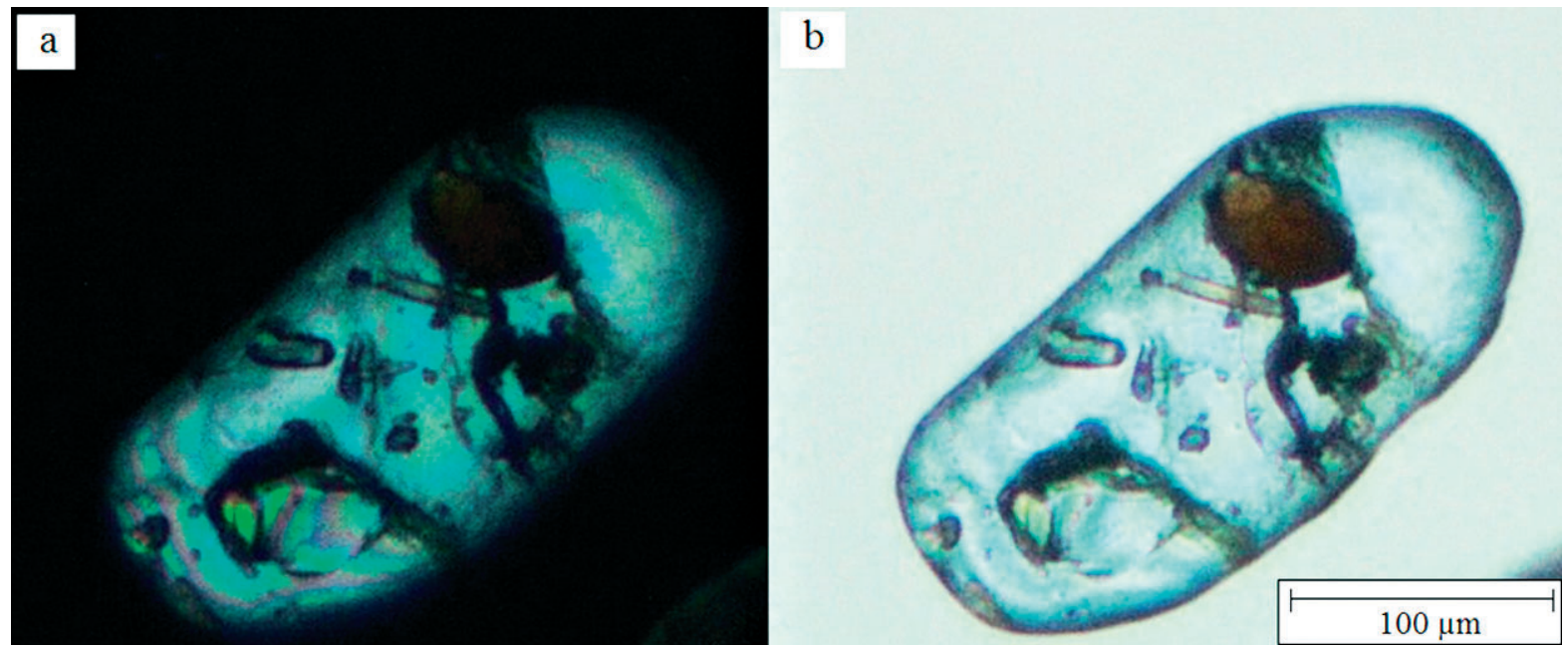

Fig. 6. Typical rounded zircon in south-western Estonia samples from Rae site (a - crossed polars, b - parallel polars). Photo by J.-I. Järvelill.

fractions shows that the finer fraction contains more feldspars (on average $29.2 \%$ ) than the coarser fraction (on average $14.4 \%$ ) (Table 1). The content of garnets and amphiboles is higher in the coarser fraction while that of zircon and monazite is higher in the finer fraction (up to $7.1 \%$ ).

To better understand and group the results of mineralogy, Agglomerative Hierarchical Clustering (AHC) analysis was made (Fig. 7). All tuples in each cluster refer to a single real-world entity, among different clusters the tuples entity is different (Doan et al., 2012).

According to AHC analysis (Fig. 7), seven groups were formed. The sites Häädemeeste 2, Häädemeeste 1, Kabli 1, and Lemmeoja 2 clearly differentiated from the other groups and also from one another. Kabli 2, Lemmeoja 3, Lemmeoja 6, Rae, and Lemmeoja 5 formed a fifth group. These sites had the highest values in terms of heavy minerals. Ikla 2, Ikla 1, Metsaküla Quarry, and Lemmeoja 4 formed a sixth group, and Pärnu and Lemmeoja 1 belong to a seventh group.

For describing the maturity levels of the sands, the zircon-tourmaline-rutile maturity index (ZTR index) (Hubert, 1962) was used with the formula:

zircon + tourmaline + rutile

total number of nonopaque heavy minerals

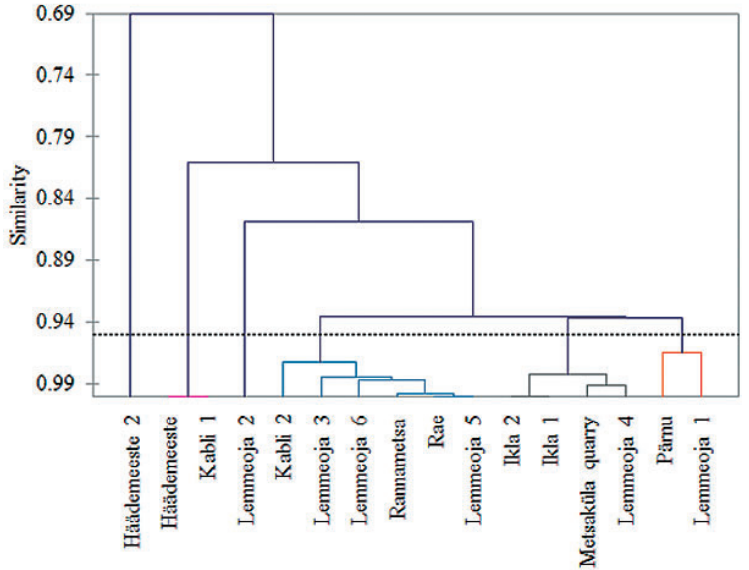

Fig. 7. A dendrogram of mineral content and samples locations according to AHC analysis (south-western Estonia). The light blue group represents sample sites with the highest content of heavy minerals.

The ZTR index is the percentage combined of zircon, tourmaline, and rutile grains amongst transparent heavy minerals. A low ZTR index shows that the sands are immature (the reason for this is that zircon, tourmaline, and rutile are very stable). The samples that have an index value below $75 \%$ are immature. According to the index, sands in the $125-250 \mu \mathrm{m}$ fraction were immature (0-24\%). In the fraction of $63-100 \mu \mathrm{m}$ the index was 7.96$21.76 \%$, showing also immature sediments. 


\subsection{Dunes in the study area}

Dune sands of the Ancylus, Litorina, and Limnea stages overlap in south-western Estonia. There is no definite boundary between Ancylus and Litorina dune sands, but Limnea-age sands are mostly situated near the sea shoreline. The coastal strip with dunes and up to $500 \mathrm{~m}$ wide beach formations passes via the contemporary shore from Pärnu to the Estonian/Latvian border, lowering towards the current shoreline. The highest dunes, over $20 \mathrm{~m}$ in height, are located near Rannametsa Village. Although Ancylus and Litorina formations are mainly located close to each other, near Tolkuse bog, the distance between them is several kilometres (Fig. 1). Aeolian sands in the study area developed from the local source material, and dunes started to form in the area immediately after source deposits on the shore became available. The process stopped when the dunes were overgrown with forest vegetation.

Depending on the initial rocks, the dip of the shore's slope, and the hydrological regime of the basin, the character of the sediments that have been formed in the coastal zone is very variable. Coastal zone sediments are formed due to the re-deposition of ancient shallow-water sediments when water level fell. Younger coastal deposits (Litorina and Limnea) are, as a rule, more finely grained than deposits of older stages. (Raukas, 1991)

\subsection{Formation of deposits in the coastal zone}

Late-Glacial and Post-Glacial coastal processes deviated little from the contemporary ones, although there were also differences that were caused notably by the alternating transgressive and regressive phases in the relative sea-level history (Raukas \& Hyvärinen, 1992). Due to the moderate uplift of the Earth's crust (Torim, 2004; Vallner et al., 1988; Zhelnin, 1958), the shoreline in the study area was relatively stable during the transgressions and therefore the transgressive coastal formations are thicker and the coastal relief forms are characterized by a greater level of clarity than the regressive ones (Raukas, 1991). It is understandable, since on a stable shoreline the material is concentrated into a narrow zone. In the course of the regressive stages, the shoreline retreated rapidly and beach erosion was less intensive; as a result, less material was produced and deposited. Furthermore, under the conditions of a retreating shoreline, new segments of beach were exposed to shore processes for a short time, and not all of the depositional features are clearly delineated.

Deposits of the transgressive phases of the Baltic Sea are more reworked than those of the regressive phases. In the course of the sea's invasion, the migration of sediments up to the shore slope caused more intensive mechanical and mineralogical differentiation in their composition. This, in turn, brought about the accumulation of heavy minerals in a number of places. Conditions for enrichment were particularly favourable in the areas in which the vertical shift of material was accompanied by long-shore transport. This primarily took place along unbroken stretches of the coast with a slow crustal uplift. Such stretches are also found in our study area.

The most intensive accumulation of heavy minerals (mainly garnets and opaque minerals) took place in the surroundings of Lemmeoja, about 50 $\mathrm{km}$ south of Pärnu. Luntz \& Maiore (1960) estimated the average content of monazite in the Lemmeoja fine sands at $0.13 \%$ and the concentration of heavy metals was as following: $\mathrm{Ti}$ 0.2-0.5 \%, Zr and Y 0.01-0.2 \%, Yb 0.01-0.05 $\%$, and Ga $0.001 \%$.

\subsection{Heavy minerals in the study area}

According to the content of the heavy minerals (zircon, tourmaline, and rutile), the ZTR index in the study area is low. The reason why the content of rutile is not very high in the studied sediments is that it is a high-grade metamorphic rock mineral (Force, 1980).

The grouping based on AHC analysis (Fig. 6) produced a group of light blue samples, whose content of heavy minerals is higher. These sediments are more strongly reworked, which suggests that they have been submitted to heavy storms or high wave 
energy. However, in terms of the ZTR index, the sands are not very mature, so they have not been reworked through long-lasting processes. This means that they formed in the course of the Litorina transgression, because after that stage no other highenergy processes have occurred.

The high content of heavy minerals in the fine fractions of sediment can be explained by the finer grain's ability to 'hide' within the interstices among the larger grains, and so smaller grains are less entrained by the flowing water (Komar \& Wang, 1984). Also, the waves have sorted the finer and coarser grains apart; as a result, the coarser fraction contains more quartz and feldspars (Komar \& Wang, 1984).

Compared to the past transgressions and regressions of the sea, nowadays waves have not so high energy. The low heavy mineral content in the backshore and beach face is a proof of this.

Shear sorting, a process termed by Inman et al. (1966) and described by Bagnold (1965), prevails in minerals. As a result of this process, heavy minerals are concentrated in thin laminations. At the Lemmeoja sites these laminations contain extremely high quantities of heavy minerals; so they could even be called placer deposits. Wave energy and gravitational processes (heavier minerals settle) in the open beaches are a driving force for accumulation (Komar \& Wang, 1984; Sasaki et al., 2014).

\section{Conclusions}

Along the eastern coast of the Gulf of Riga the content of heavy minerals in coastal deposits is high and their mineral composition is quite similar to that of the Devonian bedrock. High concentrations of garnet and zircon originate mainly in the sandstones of the Aruküla and Narva stages (Fig. 2). Amphiboles and pyroxenes are eroded from Quaternary deposits. Glaciofluvial sediments and tills are thoroughly studied in the area.

Heavy minerals are concentrated in thin laminations. Finer fractions contain more valuable heavy minerals (zircon) than coarser fractions. The highest concentrations of heavy minerals in the sediment could be found in the Litorina Sea study area. In the vicinity of Lemmeoja the heavy mineral content is so high that the sediment could be regarded even as a placer. Such a development of the sediment can be explained by the palaeoenvironmental conditions (sandy deposits, stable shoreline, long-shore transport, and heavy storms). The high content of heavy minerals indicates that these sands may have practical importance for the separation of garnets and radioactive minerals. Also, in the sites that have a high concentration of heavy minerals, high levels of radon emissions and radioactivity have been detected and described in other papers (Petersell et al., 2015).

The deposits of transgressive phases of the Baltic Sea are more reworked than those of the regressive phases. In the course of the sea's invasion to the tectonically stable areas, intensive mechanical and mineralogical differentiation of the sediments took place, causing an accumulation of heavy minerals, which may have practical importance.

\section{Acknowledgements}

The authors are grateful to Kalev Järvelill for his help in the fieldwork and Tallinn University Centre of Excellence "Natural Sciences and Sustainable Development" for funding the research. Our gratitude goes to the reviewers and editors. We thank Tiia Kaare and Tony Smitt for the linguistic assistance.

\section{References}

Bagnold, R.A., 1956. The flow of cohesionless grains in fluids. Proceedings of the Royal Society of London Series A 249, 235-297. http://dx.doi.org/10.1098/rsta.1956.0020

Borgohain, R., Khound, D.J., Bhuyan D. \& Phukan, J., 1999. Petrography of the basal sandstone unit of the Upper Assambasin. Journal of Indian Association of Sedimentologists $18,51-71$.

Doan, A., Halevy, A. \& Ives, Z., 2012. Principles of Data Integration. Elsevier, Waltham, 497 p.

Force, E.R., 1980. The provenance of rutile. Journal of Sedimentary Research 50, 485-488. http://dx.doi.org/ 10.1306/212f7a31-2b24-11d7-8648000102c1865d

Gudelis, V.K., 1961. Latest and recent vertical movements and the morphology of the seacoast of the East Baltic area. 
Bulletin Géodésique 62, 357-359. http://dx.doi.org/ $10.1007 / \mathrm{bf} 02835203$

Haila, H. \& Raukas, A., 1992. Ancylus Lake. In: Raukas, A. \& Hyvärinen, H. (eds.) Geology of the Gulf of Finland. Estonian Academy of Sciences, Tallinn, pp. 283-296. (in Russian with English summary).

Hubert, J.F., 1962. A zircon-tourmaline-rutile maturity index and the interdependence of the composition of heavy minerals assemblages with the gross composition and texture of sediments. Journal of Sedimenatary Research 32, 440-450. http://dx.doi.org/10.1306/74d70ce5-2b21$11 \mathrm{~d} 7-8648000102 \mathrm{c} 1865 \mathrm{~d}$

Inman, D.L., Ewing, D.C. \& Corliss, J.B., 1966. Coastal sand dunes of Guerro Negro, Baja California, Mexico. Bulletin of the Geologic Society of America 77, 787-802. http:// dx.doi.org/10.1130/0016-7606(1966)77[787: csdogn $] 2.0 . c 0 ; 2$

Kessel, H.J. \& Raukas, A.V., 1967. The deposits of the Ancylus Lake and Littorina Sea in Estonia. Valgus, Tallinn, 135 p. (in Russian with English summary).

Kiipli, T. \& Lutt, J., 1993. Modern sedimentation. In: Lutt, J. \& Raukas, A. (eds.) Geology of the Estonian Shelf. Estonian Geological Society, Tallinn, pp. 104-117.

Kleesment, A., 1976. About mineralogical correlation principles (using the example of Paleozoic terrigenous deposits of the Baltic). In: Narbutas, V. (ed.) The Methodology and Interpretation of the Results of Mineralogical and Geochemical Studies. Mokslas, Vilnius, pp. 44-52.

Kleesment, A., 2009. Roundness and surface features of quartz grains in Middle Devonian deposits of the East Baltic and their palaeogeographical implications. Estonian Journal of Earth Sciences 58, 1, 71-84. http://dx.doi.org/10.3176/ earth.2009.1.07

Kleesment, A. \& Mark-Kurik, E., 1997. Devonian. In: Raukas, A. \& Teedumae, A. (eds.) Geology and Mineral Resources of Estonia. Estonian Academy Publishers, Tallinn, pp. $107-124$.

Komar, P.D. \& Wang, C., 1984. Processes of selective grain transport and the formation of placers on beaches. Journal of Geology 92, 637-655. http://dx.doi.org/10.1086/ 628903.

Larsen, E.S. \& Berman, H., 1934. The Microscopic Determination of the Nonopaque Minerals. Second Edition. Geological Survey Bulletin 848, 226 p.

Luntz, A.J. \& Maiore, J.J., 1960. Heavy minerals in the Litorina accumulative terrace on the eastern coast of the Gulf of Riga. In: Questions About Accumulation and Distribution of Heavy Minerals in the Coastal Marine Sands. Academy of Sciences of the Latvian SSR, Riga, pp. 123-129. (in Russian with English summary).

Lutt, J. \& Popova, L., 1993. Mineral composition of bottom sediments. In: Lutt, J. \& Raukas, A. (eds.) Geology of the Estonian Shelf. Estonian Geological Society, Tallinn, pp. 117-138. (in Estonian with English summary).
Orviku, K., Tōnisson, H. \& Jaagus, J., 2011. Sea ice shaping the shores. Journal of Coastal Research SI64, 681-685.

Petersell, V., Jüriado, K., Raukas, A., Shtokalenko, M. \& TähtKok, K., 2015. Quaternary deposits and weathered bedrock material as a source of dangerous radon emissions in Estonia. Geologos 21, 139-147. http://dx.doi.org/ 10.1515/logos-2015-0006

Raukas, A., 1961. The mineralogy of the Estonian tills. Academy of Sciences of the Estonian SSR. PhysicoMathematical and Technical Sciences Series 10, 3, 244258. (in Russian with English summary).

Raukas, A., 1964. About heavy minerals in Estonian ancient coastal deposits. In: VII Estonian Naturalists' Day, Abstracts of Presentations. Valgus, Tallinn, pp. 72-88. (in Estonian with Russian and English summaries).

Raukas, A., 1968. On the composition and stratification of dune-sands in Estonia. In: Year-book of the Estonian Geographical Society 1966. Valgus, Tallinn, pp. 72-88. (in Estonian with Russian and English summaries).

Raukas, A., 1978. The Pleistocene Deposits of the Estonian SSR. Valgus, Tallinn, 310 p. (in Russian).

Raukas, A., 1991. Transgressions of the Baltic Sea and the peculiarities of the formation of transgressive coastal deposits. Quaternaire 2, 126-130. http://dx.doi.org/ 10.3406/quate.1991.1961

Raukas, A. \& Hyvärinen, H., 1992. Characteristics of lateand postglacial coastal forms and deposits. In: Raukas, A. \& Hyvärinen, H. (eds.) Geology of the Gulf of Finland. Estonian Academy of Sciences, Tallinn, pp. 247-254. (in Russian with English summary).

Raukas, A., Koch, R., Jüriado, K. \& Järvelill, J.-I., 2014. Anomalous radioactivity level and high concentrations of heavy minerals in Lemme area, South-West Estonia. Baltica 27, 2, 93-104. http://dx.doi.org/10.5200/ baltica.2014.27.19

Reintam, L., Raukas, A., Kleesment, A., Moora, T. \& Kährik, K., 2001. Podzolization in aeolian sands underlain by gleysol formation, during nine millennia in southwestern Estonia. Proceedings of the Estonian Academy of Sciences, Geology 50, 4, 254-281.

Sasaki, T., Rajib, M., Akiyoshi, M., Kobayashi, T., Takagi, I., Fujii T. \& Zaman, M., 2014. Laboratory enrichment of radioactive assemblages and estimation of thorium and uranium radioactivity in fractions separated from placer sands in Southeast Bangladesh. Natural Resources Research 24, 2, 209-220. http://dx.doi.org/10.1007/ s11053-014-9248-6

Soomere T., Viška M., Lapinskis J. \& Räämet A., 2011. Linking wave loads with the intensity of erosion along the coasts of Latvia. Estonian Journal of Engineering 17, 4, 359374. http://dx.doi.org/10.3176/eng.2011.4.06

Stoiber, R.E. \& Morse, S.A., 1994. Crystal Identification with the Polarizing Microscope. Chapman \& Hall, London, 358 p. http://dx.doi.org/10.1007/978-1-4615-2387-1 
Suursaar, Ü., Kullas, T. \& Aps, R., 2012. Currents and waves in the northern Gulf of Riga: measurement and long-term hindcast. Oceanologia 54, 3, 421-447. http://dx.doi.org/ $10.5697 /$ oc. $54-3.421$

Torim, A., 2004. About land uplift and changes of coastline in Estonia. Geodeet 28, 52, 57-62. (in Estonian).

Vallner, L., Sldvee, H. \& Torim, A., 1988. Recent crustal movements in Estonia. Journal of Geodynamics 9, 215233. http://dx.doi.org/10.1016/s0264-3707(88)80066-8 Viiding, H., 1962. On the mineralogic composition of Estonian
Middle-Devonian sandstones. Academy of Sciences of the Estonian SSR, Institute of Geology, Studies 10, 270-290. (in Russian).

Viiding, H., 1964. About lithology and mineralogy of sand and silt deposits in the Devonian of the Estonian SSR. In: Karatajute-Talimaa, V.N. \& Narbutas, V.V. (eds.) Questions of Stratigraphy and Paleogeography of the Devonian Baltic. Minthis, Vilnius, pp. 4-83. (in Russian). Zhelnin, G., 1958. Uplift of the Earth's crust in Estonia. Eesti Loodus 5, 269-274. (in Estonian). 